\title{
Use of cell morphology to evaluate the effect of a peroxidase gene on cell death induction thresholds in tobacco
}

\author{
Emma Burbridge $^{\mathrm{a}}$, Mark Diamond ${ }^{\mathrm{b}}$, Philip J. Dix ${ }^{\mathrm{a}}$, Paul F. McCabe ${ }^{\mathrm{b}, *}$ \\ ${ }^{a}$ Institute of Bioengineering and Agroecology, Department of Biology, National University of Ireland Maynooth, Maynooth, Co. Kildare, Ireland \\ ${ }^{\mathrm{b}}$ School of Biology and Environmental Science, University College Dublin, Dublin 4, Ireland
}

Received 2 March 2006; accepted 6 March 2006

Available online 3 April 2006

\begin{abstract}
Tobacco suspension cultures were subjected to a range of heat stresses and used to compare morphological aspects of programmed cell death (PCD) and necrosis. Cells undergoing PCD were found to display characteristic death morphology, caused by cytoplasmic retraction of the protoplast, and to have cleaved DNA. We evaluated if the morphological characteristics of PCD could be used to monitor changes in cell death induction thresholds in transgenic cell cultures with high levels of peroxidase activity. Again, using a heat shock assay, we show that tobacco cell cultures with elevated levels of peroxidase have higher cell death induction threshold levels than wild type tobacco cell cultures. Thus, assessing PCD associated morphological changes can report on the effect of altering peroxidase genes on cell death activation in tobacco. This study demonstrates that PCD morphology could routinely be used to monitor the effects of introduced genes on programmed cell death induction thresholds in plants.
\end{abstract}

(C) 2006 Elsevier Ireland Ltd. All rights reserved.

Keywords: Programmed cell death; Heat-shock; Peroxidase

\section{Introduction}

Plant cells die in a number of ways. Two such death pathways include PCD and necrosis. Programmed cell death (PCD) is an active, genetically organized, process, which brings about the controlled disassembly of the cell. Necrosis is an uncontrolled type of cell death characterised by the cell losing its ability to osmoregulate leading to the cell swelling, bursting and releasing its cellular contents. Whether a biotic or abiotic stress initiates necrosis or PCD is generally dependent on the actual stress-dosage: low levels of stress induce cellular protective mechanisms, higher levels trigger PCD and higher levels again lead to necrosis. McCabe et al. [1] demonstrated this dose-dependence by killing carrot cells with increasing temperatures. They showed that plant cells that undergo PCD following moderate heat stresses die in such a way that the resultant corpse displays several hallmark features indicative of

\footnotetext{
Abbreviations: PCD, programmed cell death; ROS, reactive oxygen species

* Corresponding author. Tel.: +3531716 2251; fax: +35317161153.

E-mail address: paul.mccabe@ucd.ie (P.F. McCabe).
}

the PCD programme. Morphologically, the PCD protoplast condensed, leaving a visible gap between the cell wall and plasma membrane; additionally, nuclear DNA was cleaved, often into nucleosomal fragments [1,2].

PCD is essential for normal plant development and is an important component of a plants pathogen defence arsenal. However, the signalling mechanism that triggers PCD, or indeed the actual mechanism of cellular destruction, is poorly understood in plants. One set of molecules that have been implicated in both signalling and triggering the cell death cascade are reactive oxygen species (ROS). ROS levels in cells are influenced by peroxidases that are widely distributed among living organisms. Peroxidases have a multiplicity of physiological and biochemical roles in plants. Such roles include the cross-linking of molecules in the cell wall, auxin oxidation, lignin production and responses to biotic and abiotic stresses [3-5]. Peroxidase can regulate ROS within a cell by altering levels of hydrogen peroxide $\left(\mathrm{H}_{2} \mathrm{O}_{2}\right)$. Peroxidase utilises $\mathrm{H}_{2} \mathrm{O}_{2}$ in the oxidation of many substrates such as lignin monomers [6-8] but paradoxically, it can also mediate the production of $\mathrm{H}_{2} \mathrm{O}_{2}$. This dual role of peroxidase means that it can play a part in $\mathrm{H}_{2} \mathrm{O}_{2}$ regulation. A reaction scheme for the production of $\mathrm{H}_{2} \mathrm{O}_{2}$ by cell wall peroxidases at the expense of NADPH 
oxidase has been elucidated by Elstner and Heupel [9]. Plant homologues of two NADPH oxidase components, gp91 ${ }^{\text {phox }}$ and Rac have been cloned [10,11] and Kawasaki et al. [11] have shown that Rac protein might mediate the hypersensitive response (HR) in a ROS-dependent manner. A second proposed source for $\mathrm{H}_{2} \mathrm{O}_{2}$ involves an apoplastic peroxidase [12,13]. The $\mathrm{O}_{2}$-heme complex of peroxidase is reduced to compound III and, under alkaline conditions, the complex is effectively catalysed to release $\mathrm{H}_{2} \mathrm{O}_{2}$.

Cells challenged by hypersensitive response elicitors will generate $\mathrm{H}_{2} \mathrm{O}_{2}$ which has threshold-specific effects on the plant cells: low doses induce antioxidant enzymes such as glutathione peroxidase preventing cellular damage, higher doses leads to programmed cell death (PCD) and very high levels lead to necrotic cell death [14]. $\mathrm{H}_{2} \mathrm{O}_{2}$ has also been shown to be a potent inducer of programmed cell death when added directly to plant cell cultures [1,15-17]. Houot et al. [17] have shown that $\mathrm{H}_{2} \mathrm{O}_{2}$ can induce $\mathrm{PCD}$, in a process similar to animal apoptosis, but only in a dose-dependent manner. Catalase deficient cell lines have been used to show that an increase in $\mathrm{H}_{2} \mathrm{O}_{2}$ levels induces PCD suggesting that changes in $\mathrm{H}_{2} \mathrm{O}_{2}$ homeostatis can trigger PCD [18]. These findings demonstrate that $\mathrm{H}_{2} \mathrm{O}_{2}$ can play a role in cell death signalling. Since peroxidase can regulate the available levels of $\mathrm{H}_{2} \mathrm{O}_{2}$ within the cell, it may be able to influence the induction thresholds at which cell protection, PCD or necrosis are activated and may therefore be a key enzyme in manipulating these processes in plants.

We wished therefore to investigate the effect that overexpressing peroxidase genes may have on cell death rates in plants. We speculated that over-expressing peroxidase genes would have an effect on PCD rates but were unable to predict if this effect would be to lower or raise the threshold levels at which abiotic stress would trigger PCD. Tobacco has been shown to be an ideal model species to examine and identify the physiological effects of over and under expression of genes [19-21]. In this report, we established that a heat treatment could activate PCD or necrosis in tobacco cell cultures and, as has been shown in Arabidopsis and carrot [2], PCD in tobacco results in a condensed cytoplasm and PCD induced cleavage of DNA. We have utilised the cell morphology to report on cell death rates following heat treatment and were therefore able to evaluate, and report on, the effect of an introduced peroxidase gene on cell death rates in tobacco.

\section{Materials and methods}

\subsection{Plant material}

Nicotiana tabacum L. cv. Xanthi seeds were surface sterilised in $10 \%(\mathrm{w} / \mathrm{v})$ hypochlorite and germinated on half strength MS medium [22]. Tobacco plants were maintained in a growth room at $25{ }^{\circ} \mathrm{C}$ under a 16-h light/8-h dark photoperiod regime. Tobacco leaf strips were placed on MS medium supplemented with $2 \mathrm{mg} / \mathrm{l} \mathrm{NAA}$ and $0.25 \mathrm{mg} / \mathrm{l} \mathrm{kinetin}$ to induce calli formation. Two hundred and fifty millilitre conical flasks with $50 \mathrm{ml}$ of cell culture medium (MS medium supplemented with $100 \mathrm{mg} / \mathrm{l}, 2$,4-D and $100 \mathrm{mg} / \mathrm{l} \mathrm{kinetin)}$ were inoculated with friable callus to initiate cell suspensions and kept at $25{ }^{\circ} \mathrm{C}$, under continuous light and on a rotary shaker at $110 \mathrm{rpm}$. Cell suspension cultures were subcultured at 10-day intervals by pipetting $10 \mathrm{ml}$ of cell culture into $45 \mathrm{ml}$ of fresh cell culture medium.

\subsection{Induction and measurement of cell death}

Seven-day-old cell cultures were centrifuged at $1500 \mathrm{rpm}$ for $5 \mathrm{~min}$ to pellet cells. The medium was removed and replaced with fresh medium without growth regulators. The cells were then heat-shocked for $20 \mathrm{~min}$ at different temperatures, ranging from 25 to $85^{\circ} \mathrm{C}$, and then returned to $25^{\circ} \mathrm{C}$ shaking at $100 \mathrm{rpm}$ for $24 \mathrm{~h}$. An equal volume of cells and fluorescein diacetate (FDA; a 0.1\%, w/v, stock diluted 1:50 with culture medium), were placed on a microscope slide. Epifluorescence was observed through a fluorescein isothiocyanate (FITC) filter. Only single cells and cells in groups of $<6$ were counted. Cells that did not stain with FDA were scored as dead. Cells whose cytoplasm had condensed and shrunken were scored as having undergone PCD. Cells that were FDA negative but showed no sign of cytoplasm condensation were scored as necrotic.

\subsection{DNA extraction}

DNA was isolated from the cells using a modified CTAB method. Cells were frozen and ground in liquid nitrogen. The powder was suspended in CTAB buffer (2\% CTAB, $100 \mathrm{mM}$ Tris, pH 8, 20 mM EDTA, $\left.1.4 \mathrm{M} \mathrm{NaCl}, 1 \% \operatorname{PVP}\left(M_{\mathrm{W}} 40,000\right)\right)$ and incubated at $65^{\circ} \mathrm{C}$ for $60 \mathrm{~min}$. The supernatant was RNase A $(10 \mathrm{mg} / \mathrm{ml})$ treated at $37^{\circ} \mathrm{C}$ for $30 \mathrm{~min}$. An equal volume of chloroform: isoamyl alcohol (24:1) was added and mixed well. The DNA was precipitated with $0.6 \times$ isopropanol, washed in $70 \%$ ethanol, dried and resuspended in TE buffer. The DNA was then resolved on a $1.5 \%$ agarose gel.

\subsection{Cloning of the barley peroxidase construct}

A two-step cloning strategy was used to insert a barley peroxidase gene into a bar containing Ti-plasmid. A $1.2 \mathrm{~kb}$ Pst I/Sph I fragment of the cDNA clone, pBH6-301 [23], was cloned into the Pst I and Sph I sites a pPS48 vector derived from pBI121 (Clontech), which provided the enhanced cauliflower mosaic virus CaMV-35S promoter and terminator. A resulting $2.2 \mathrm{~kb}$ HindIII fragment was then isolated and cloned into the HindIII site of the Ti-plasmid CAMBIA 3301 and renamed HvHvPrx83201. The CAMBIA vector contained the Basta selection gene and the $\beta$-glucuronidase (GUS) reporter gene under the control of the CaMV-35S promoter. A positive clone was transformed into Escherichia coli (DH5 $\alpha$ ) using kanamycin as a selection pressure and positive clones were identified by PCR using the following primers: TDT15 [AACAGTCGTGGAAGTGCAGC] and 35S reverse [ACTGACGTAAGGGATGACGC]. Clones were also checked by sequencing using a DNA sequencer model ABI 373, Perkin-Elmer. 


\subsection{Transformation}

The construct was transformed into Agrobacterium tumefaciens (C58C1) using a freeze-thaw method as described previously [24] and into N. tabacum L. cv. Xanthi using a modified form of the leaf disc Agrobacterium-mediated transformation procedure [25]. Briefly, $1 \mathrm{~cm}^{2}$ leaf discs were cut with a cork borer, placed into the bacterial suspension and left for 15-30 min with gently shaking. The discs were dried on sterile filter paper and placed onto co-cultivation medium (MS medium, coated with $150 \mu \mathrm{l}, 10 \mathrm{mM}$ acetosyringone ( $\mathrm{pH} \mathrm{5.1)}$ and $15 \mu \mathrm{l}, 1 \mathrm{M}$ betaine, 1 day before use) for 2 days. The discs were then transferred to a shoot-inducing medium (MS medium supplemented with $0.1 \mathrm{mg} / \mathrm{l} \mathrm{NAA}, 1 \mathrm{mg} / \mathrm{l} \mathrm{BA}, 1 \mathrm{mg} / \mathrm{l}$ thiamine$\mathrm{HCl}$ supplemented with $100 \mathrm{mg} / \mathrm{l}$ vancomycin, $100 \mathrm{mg} / \mathrm{l}$ timentin, $100 \mathrm{mg} / \mathrm{l}$ cefotaxime, to prevent the overgrowth of Agrobacterium and $10 \mathrm{mg} / \mathrm{l}$ Bialaphos (selective agent)). Regenerated shoots were excised after developing two leaves and placed onto MS medium to induce root formation, again supplemented with $100 \mathrm{mg} / \mathrm{l}$ vancomycin, $100 \mathrm{mg} / \mathrm{l}$ timentin, $100 \mathrm{mg} / \mathrm{l}$ cefotaxime and $10 \mathrm{mg} / \mathrm{l}$ Bialaphos. The reporter gene uidA encoding the enzyme $\beta$-glucuronidase [26] is used as a histochemical marker to identify putative transformants. A small amount of leaf tissue was immersed in the incubation solution (0.1 $\mathrm{M} \mathrm{Na}_{2} \mathrm{PO}_{4}, 10 \mathrm{mM}$ EDTA, $0.5 \mathrm{mM}$ potassium ferricyanide, $0.5 \mathrm{mM}$ potassium ferrocyanide, $1.0 \mathrm{mM} \mathrm{X}$-gluc (5-bromo-4chloro-3-indolyl $\beta$-D-glucuronide), $0.1 \%$ Triton X-100) and left overnight at $37^{\circ} \mathrm{C}$ [27]. The following day the tissue was incubated in ethanol to remove chlorophyll and to allow for the observation of the blue spots caused by the expression of $\beta$ glucuronidase. Rooted plants were screened for the presence of the transformed gene by PCR. Briefly, a master mix consisted of $1 \times$ PCR buffer, $\mathrm{MgCl}_{2}$ to a final concentration of $0.05 \mathrm{mM}$, $300 \mu \mathrm{m}$ HvPrx 8 forward, $300 \mu \mathrm{m}$ HvPrx 8 reverse, dNTP mix to a final concentration of $200 \mu \mathrm{m}$ and $1.5 \mathrm{U}$ of Taq DNA polymerase. The PCR conditions were as follows: $96{ }^{\circ} \mathrm{C}$ for $1 \mathrm{~min}$, followed by 30 cycles of $96^{\circ} \mathrm{C}$ for $20 \mathrm{~s}, 55^{\circ} \mathrm{C}$ for $20 \mathrm{~s}$, $72{ }^{\circ} \mathrm{C}$ for $2 \mathrm{~min}$ and then finishing with $10 \mathrm{~min}$ at $72{ }^{\circ} \mathrm{C}$. Tobacco plants that proved PCR positive were analysed for peroxidase activity. Once transformed plants were established, they were gradually weaned off the antibiotics by reducing the concentrations at periods of subculturing.

\subsection{Protein extraction and peroxidase activity assay}

Leaf material $(100 \mathrm{mg} / \mathrm{ml})$ was homogenized in $50 \mathrm{mM}$ sodium phosphate buffer, $\mathrm{pH} 6.2$ and centrifuged at 13,000 rpm for $10 \mathrm{~min}$. The supernatant was used as total soluble protein. Total protein was quantified according to the standard Bio-Rad method, with BSA as the standard protein [28]. Activity of all samples was determined using the peroxidase substrate guaiacol. The reaction mixture consisted of $0.28 \%$ guaiacol and $0.30 \% \mathrm{H}_{2} \mathrm{O}_{2}$ in $0.05 \mathrm{M} \mathrm{Na}_{2} \mathrm{HPO}_{4}, \mathrm{pH}$ 6.2. The sample extract $(1-20 \mu \mathrm{l})$ was added to $1 \mathrm{ml}$ of reaction mixture and the increase in absorbance was followed for $3 \mathrm{~min}$ at $30 \mathrm{~s}$ intervals at $420 \mathrm{~nm}$. The rate of this reaction was used to express peroxidase activity.

\section{Results}

\subsection{Heat shock induces programmed cell death morphology in N. tabacum cell cultures}

Tobacco cell suspension cultures were chosen to investigate rates of PCD in wild type and transgenic plants. Cell cultures are amenable to this type of study as they are usually made up of rapidly dividing undifferentiated cells and are therefore relatively uniform. In addition, cells in culture are relatively assessable and a count of large numbers per treatment is straightforward. Fig. 1A demonstrates the morphology of a healthy living cell. Carrot and Arabidopsis cells, which have died by a $55^{\circ} \mathrm{C}$ heat-induced PCD, have a very distinct morphology. Tobacco cells subjected to $55^{\circ} \mathrm{C}$ for $20 \mathrm{~min}$ also display these PCD associated morphological characteristics (Fig. 1B). Following PCD inducing heat treatment, the protoplast condenses and the cell membrane retracts and moves away from the cell wall leaving a visible gap. As in carrot and Arabidopsis [1,2] cells, which were FDA negative but did not display the PCD morphology, were deemed to have been overwhelmed by stress and have died necrotically (Fig. 1C). In order to determine the levels of stress which result in either living, PCD or necrotic cells, cells from 7-day-old wild type tobacco cell cultures were harvested and subjected to a range of short heat treatments, as described in ref. [1]. The absence of FDA staining was plotted, as was the percentage of cells having died via PCD (FDA negative + cytoplasmic retraction). Fig. 1D shows that, from 25 to $55^{\circ} \mathrm{C}$, there is a steady increase in total cell death (FDA negative) in the culture. Practically, all these deaths are accompanied by the PCD morphology of retraction of the cytoplasm away from the cell wall. However, from 55 to $85^{\circ} \mathrm{C}$, the number of cells that die via PCD drops dramatically while conversely the number of cells dying via necrosis rises.

\subsection{Heat shock triggers a PCD-induced cleavage in $N$. tabacum cell cultures}

Confirmation of the activation of PCD was established by assaying for DNA cleavage. Cells from 7-day-old wild type tobacco cell cultures were heat-shocked at $55^{\circ} \mathrm{C}$ for $20 \mathrm{~min}$, returned to $25^{\circ} \mathrm{C}$ and checked at regular intervals for $\mathrm{PCD}$ morphology. Even though PCD morphology was evident from $4 \mathrm{~h}$ after the treatment, we extracted total genomic DNA after $24 \mathrm{~h}$ as McCabe and Leaver [2] showed that initial PCD-induced cleavage generally begins $5-7 \mathrm{~h}$ after heat treatments with cleavage only becoming detectable after $12-24 \mathrm{~h}$. Total genomic DNA extracted from cells subjected to $55^{\circ} \mathrm{C}$ for $20 \mathrm{~min}$ was separated by electrophoresis on a $1.5 \%$ agarose gel along with genomic DNA from untreated cells. Evidence of DNA cleavage was detected $24 \mathrm{~h}$ after the PCD inducing heat treatment (Fig. 2).

\subsection{PCR analysis and peroxidase activity of putative transformants}

The transgenic nature of the resulting plant lines was established by $\beta$-glucuronidase (GUS) assay, PCR analysis and 
(A)

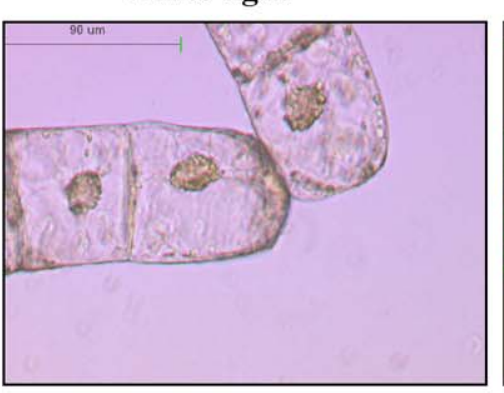

FDA + 490nM light

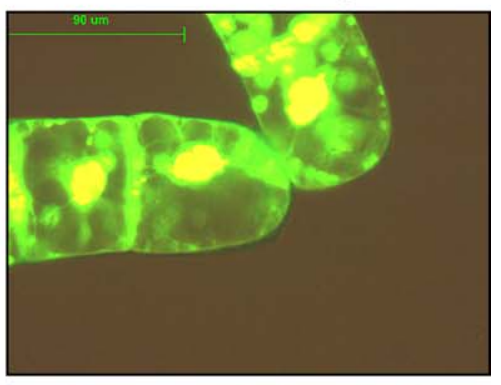

(B)
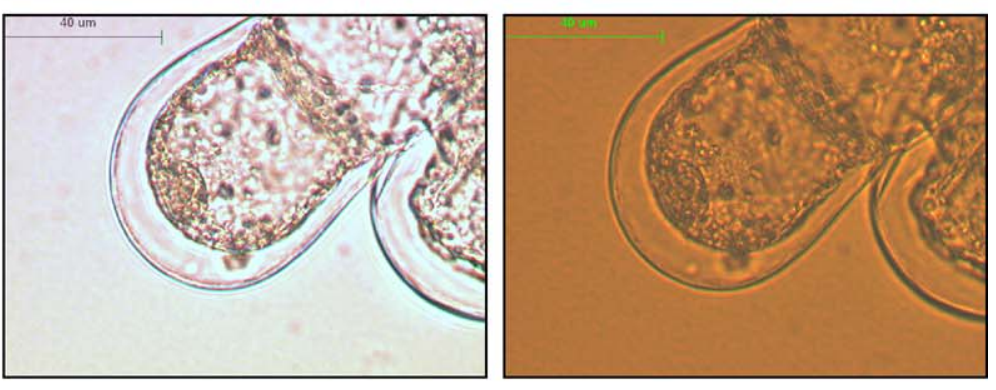

(C)
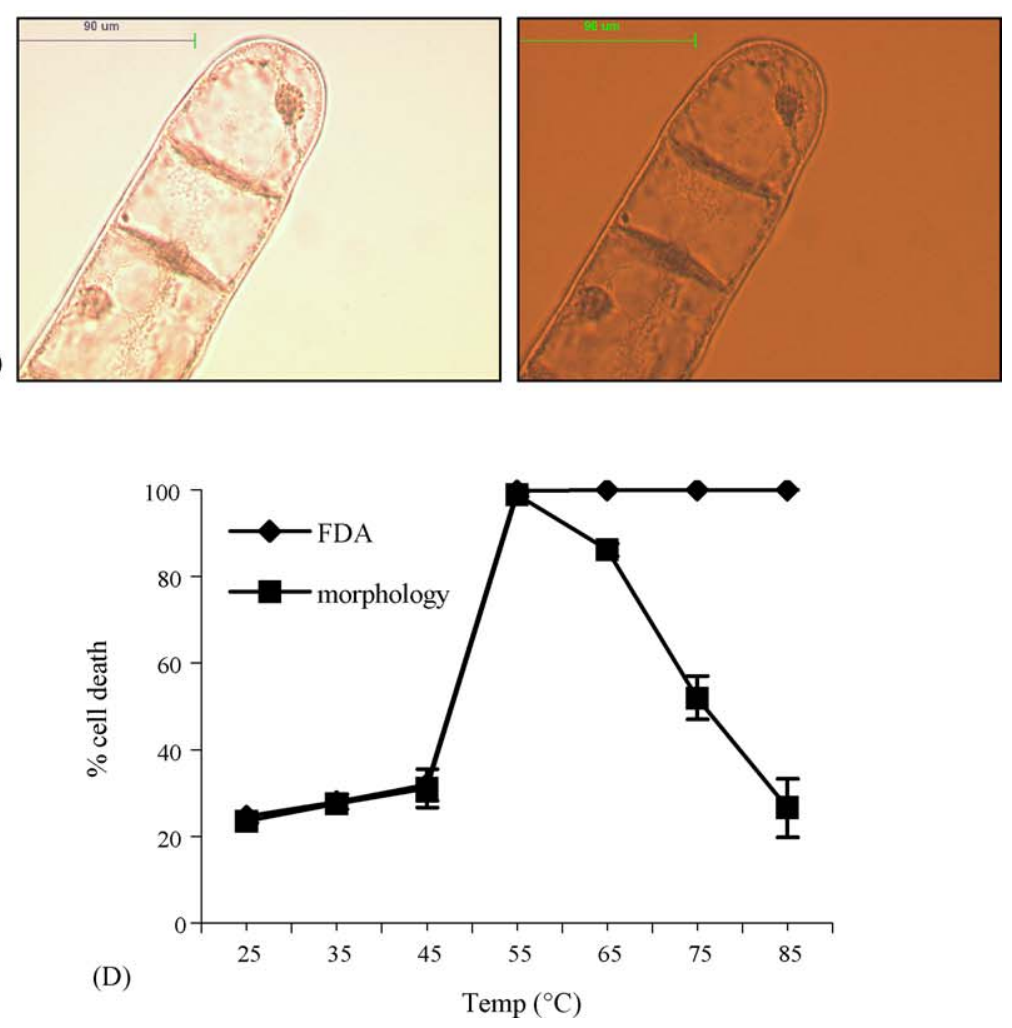

Fig. 1. Identification of live cells, necrotic cells and cells that have undergone PCD using FDA and cell morphology. (A) Cells that are alive have the ability to cleave FDA and fluoresce under light at a wavelength of $490 \mathrm{nM}$. (B) In cells that undergo PCD, the protoplast retracts from the cell wall. (C) Necrotic cells cannot cleave FDA so do not fluoresce and show no evidence of protoplast condensation. (D) Wild type cells were subjected to different heat treatments for 20 min and returned to $25^{\circ} \mathrm{C}$ for $24 \mathrm{~h}$. Cells were then scored under the light microscope for PCD morphology. The percentage of PCD cells was determined. The cells were also stained with FDA and examined under UV light to determine whether living or dead.

peroxidase activity assays. The first test carried out on these putative transformants was the GUS assay. A blue colour was observed when this reporter gene was expressed. The GUS assay is extremely useful as it is sensitive enough to detect expression within a single cell type and only a small amount of tissue is required. When a shoot began to develop on rooting medium a small amount of leaf tissue was removed and incubated in substrate solution. All rooting shoots were tested for GUS expression and all shoots that tested positive were maintained on rooting medium for further analysis. The presence of the gene was also confirmed by PCR. The primers, HvPrx8 forward [TGTTCAACAACGACACCACC] and 


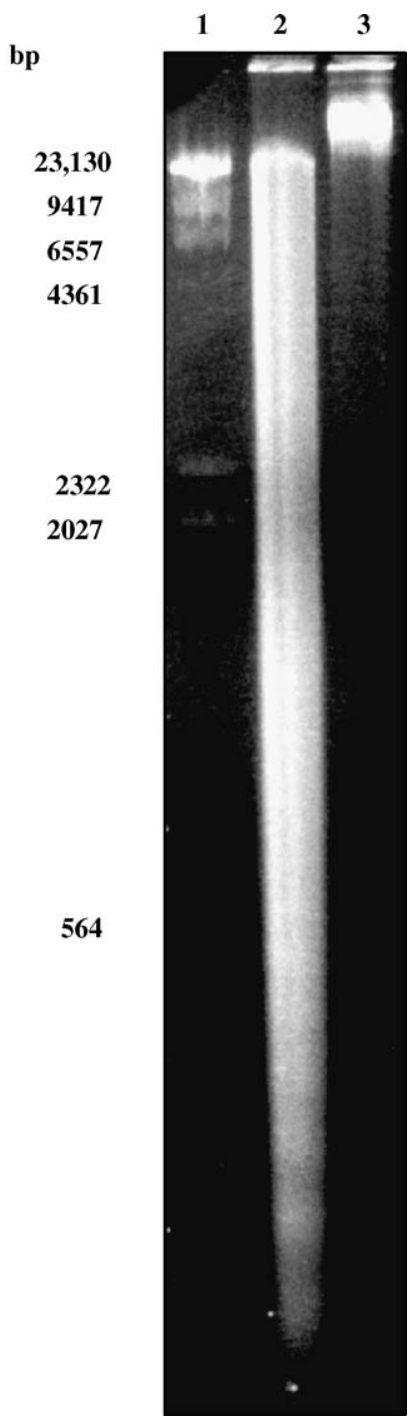

Fig. 2. Detection of DNA fragmentation in wild type tobacco cells induced to die by heat shock. Cells were subjected to $55^{\circ} \mathrm{C}$ heat treatments for $20 \mathrm{~min}$ and $24 \mathrm{~h}$ later DNA was extracted and run on a $1.5 \%$ agarose gel. Lane 1 contains the $\lambda$-HindIII marker, lane 2 shows DNA from heat-treated cells and lane 3 shows DNA from cells not subjected to heat treatment.

HvPrx8 reverse [CATTCACGTGTCGTGCTAGC] amplified a $277 \mathrm{bp}$ product which corresponded to the expected size of the introduced peroxidase gene (data not shown). Total soluble protein was isolated from leaf tissue and measured as described in Section 2. Peroxidase activity was determined using the peroxidase substrate guaiacol. Fig. 3A shows the peroxidase activity calculated for four representative tobacco plants transformed with the HvPrx83301 plasmid. Line HvPrx8.31 had the highest peroxidase activity.

\subsection{Induction of cell death in tobacco cell cultures expressing a defence-related barley peroxidase}

We used the heat shock assay to evaluate possible PCD activation differences in the sensitivity of wild type tobacco, and tobacco expressing barley peroxidase, following abiotic stress.
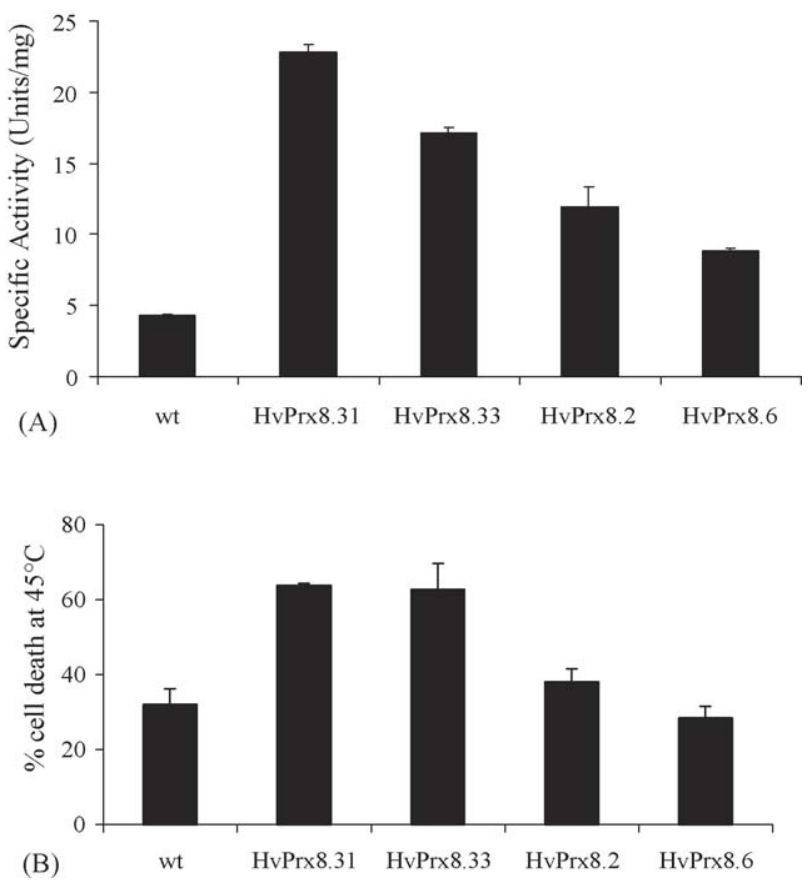

Fig. 3. Peroxidase activity and cell death rates in tobacco plants transformed with the HvPrx83201 plasmid. (A) Guaiacol peroxidase activity was determined in leaf material of primary transformants expressing the barley peroxidase gene, $H v \operatorname{Pr} x 8$, under the control of the $35 \mathrm{~S}-\mathrm{CaMV}$ promoter. The results are the mean of three experiments. (B) Cells were subjected to a $45{ }^{\circ} \mathrm{C}$ heat shock treatment for $20 \mathrm{~min}$ and then returned to $25^{\circ} \mathrm{C}$ for $24 \mathrm{~h}$. Cells were then scored under the light microscope for PCD morphology. The percentage of PCD cells was determined. The cells were also stained with FDA and examined under UV light to determine whether living or dead.

Four independent transformants were first subjected to a $45{ }^{\circ} \mathrm{C}$ heat shock treatment. This temperature was chosen as it is on the boundary of the transition from cell staying alive to cells activating PCD (Fig. 1D). Any changes in PCD induction thresholds should be evident at this temperature. The percentage of cell death in four cell lines is shown in Fig. 3B. The cell line HvPrx8.6, which marginally over-expresses peroxidase shows no, or little, change in cell death rates at $45^{\circ} \mathrm{C}$. Cell line HvPrx8.2 has higher peroxidase levels and shows a small increase in cell death rates, while cell lines HvPrx8.31 and HvPrx8.33, with higher peroxidase activity again, have significant increases in cell death induction (Fig. 3A and B).

Using the HvPrx8.31 cell line, we subjected cells to a range of temperatures to investigate PCD activation at several temperatures including necrotically inducing levels of stress. Fig. 4A shows that the overall pattern of increased induction of PCD up to $55^{\circ} \mathrm{C}$ and increased necrosis from 55 to $85^{\circ} \mathrm{C}$ is very similar to the wild type response. Fig. 4B was created by combining the PCD morphology scores for wild type (Fig. 1D) and peroxidase over-expressing tobacco (Fig. 4A). In relation to the activation of PCD, there are two apparent trends that can be seen in Fig. 4B. Firstly, at temperatures below $55{ }^{\circ} \mathrm{C}$, PCD is consistently higher in the peroxidase transgenic line. In fact, at $45^{\circ} \mathrm{C}$, the PCD rate is almost two-fold higher in the peroxidase transgenic than it is in the wild type cells. The second trend can be seen in temperatures of $55^{\circ} \mathrm{C}$ and above where, this time, the 

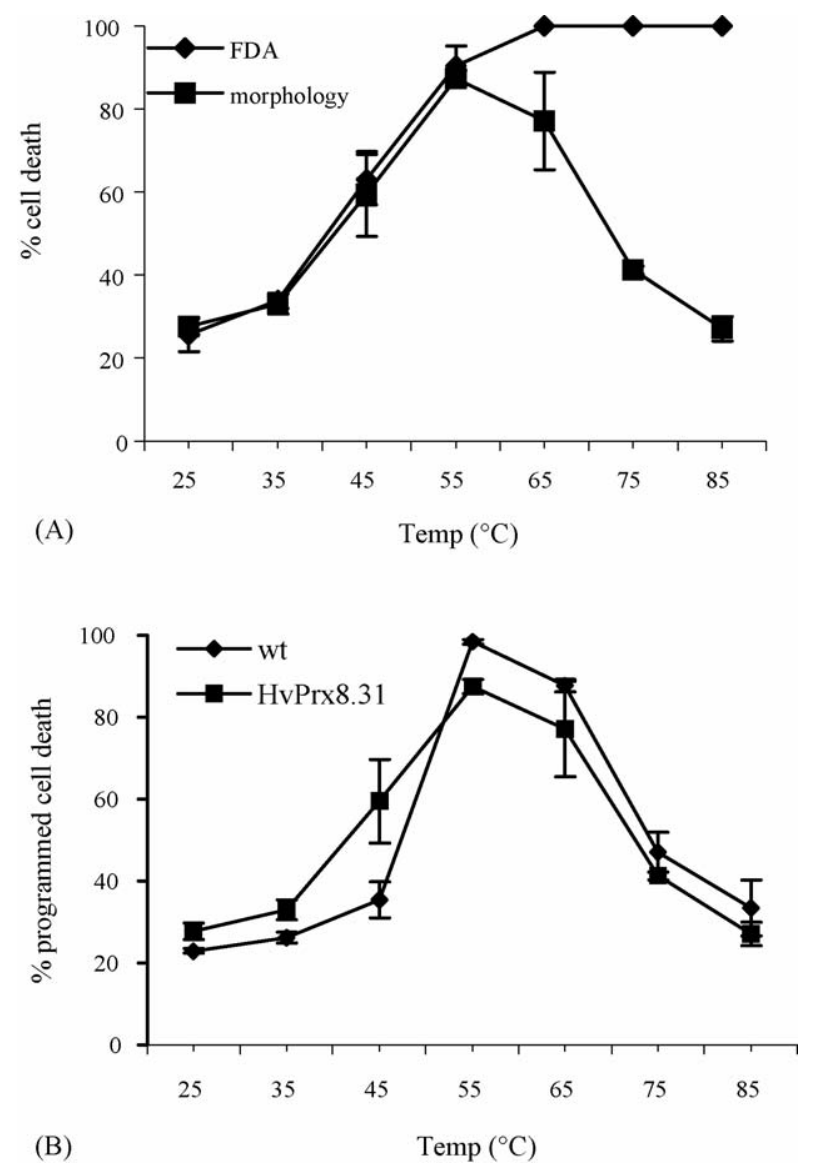

Fig. 4. Induction of programmed cell death in cell cultures expressing barley peroxidase, HvPrx8. (A) Cells, which were transformed with barley peroxidase, HvPrx8, were treated in the same way as wild type cells and scored as outlined above. Data shown are representative of three independent replicate experiments. Error bars represent standard error of the mean that is derived from numerous independent fields of at least 100 cells. (B) Morphology data from Figs. 1D and 4A were combined to compare PCD activation in wild type and transgenic tobacco expressing barley peroxidase.

peroxidase transgenic cells consistently undergo less PCD than the wild type cells.

\section{Discussion}

w? >McCabeetal.[1,2] havedevelopedaninduciblecelldeath assaywithwhichtheycandistinguishlivingcells, thoseundergoing PCDandnecroticcells. Thisassayinvolvessubjectingsuspension culture cells to a range of temperatures over short periods. They could thenanalyseaspects ofcelldeathusingFDA staining, PCDspecific morphology and DNA cleavage. The ability to define exactlyhowmanycellshavediedandtoseparatePCDfromnecrotic celldeathallowsonetoscore forsubtlechangesincelldeathrates. This assay has been shown to work equally well with carrot and Arabidopsis cells [2].

In this paper, we have extended the assay to tobacco. We confirm that, as found in Arabidopsis and carrot [2] death induced by heat stress occurs via necrosis or PCD. At temperatures up to $55^{\circ} \mathrm{C}$, when cells die they activate PCD, however, at temperatures above $55^{\circ} \mathrm{C}$ necrotic cell death predominates.
This biphasic pattern of cell death has been reported for other plant species [1,2] and human cell lines [29]. The pattern can also be repeated with a range of different noxious agents including $\mathrm{H}_{2} \mathrm{O}_{2}[30,15,1]$. In the current study, PCD in tobacco cell cultures was accompanied by the characteristic heat-induced PCD morphology of cytoplasmic retraction, with practically all cells undergoing this form of PCD at $55{ }^{\circ} \mathrm{C}$. PCD was confirmed by demonstrating that the dead cells at $55^{\circ} \mathrm{C}$ were FDA negative and that their DNA had been cleaved.

As can be seen from our results, $55^{\circ} \mathrm{C}$ is a pivotal temperature in the heat shock assay, the point at which necrosis replaces $\mathrm{PCD}$ as the predominant cellular death mechanism. At temperatures of up to $55{ }^{\circ} \mathrm{C}$, cells are damaged by heat stress and will either, repair the damage and survive, or activate their programmed cell death mechanisms. Above $55^{\circ} \mathrm{C}$, the cellular damage is so severe that staying alive is no longer an option for cells. In this temperature range, cells will die and the challenge for the cell now is to activate a controlled programmed cell death and to avoid uncontrolled necrotic cell death.

The life or death choices a cell ultimately makes may be determined be a wide range of physiological considerations. Certainly, one such important consideration in determining whether a cell survives or mounts a PCD versus necrotic response may be determined by the redox state of the cell. Herein, we wished to see if we could utilise the heat stress assay to investigate the effect of over-expressing genes that may be involved in redox-associated signalling, or induction of cell death pathways, in tobacco. We chose to introduce a barley peroxidase gene into tobacco. There is documented evidence to suggest that peroxidase can generate $\mathrm{H}_{2} \mathrm{O}_{2}$ during the oxidative burst [12]. $\mathrm{H}_{2} \mathrm{O}_{2}$ is relatively stable and inert but it can produce the hydroxyl radical $\left(\mathrm{OH}^{\bullet}\right)$, which is highly reactive and can initiate radical cascade reactions that lead to the rapid oxidation of lipid, proteins and nucleic acids. The HvPrx83201 plasmid was constructed incorporating a peroxidase gene, which was found to accumulate in response to the powdery mildew fungus attack [23]. This is possibly due to the induction of the hypersensitive response, which culminates in cell death following the rapid production of ROS. Since barley peroxidase in tobacco has been located to the apoplast, there is a strong conviction that this peroxidase could be a source of ROS [27].

Introduction of the peroxidase genes can lead to an increase in PCD in cells heat-shocked at $45^{\circ} \mathrm{C}$. It was seen that the transgenics with the highest peroxidase activity have the largest increase in cell death rates. In wild type cells, a $45{ }^{\circ} \mathrm{C}$ heat stress is on the border of the PCD induction threshold, cells while obviously stressed can cope with this stress and survive, certainly for at least $24 \mathrm{~h}$. However, cell lines over-expressing high levels of peroxidase are much more likely to activate PCD following a $45^{\circ} \mathrm{C}$ stress.

The balance of ROS within a cell has been shown to be critical to cell death decisions. For example, Levine et al. [15] demonstrated that $\mathrm{H}_{2} \mathrm{O}_{2}$ at low levels induce the protective gene glutathione S-transferase, at higher levels induces PCD and at higher levels again causes necrosis. The necrosis caused by extremely high levels of $\mathrm{H}_{2} \mathrm{O}_{2}$ is probably due to overwhelming lipid peroxidation and protein degradation. At PCD-inducing 
levels, ROS will induce oxidative stress which is known to trigger the permeability transition (PT) pore opening in mitochondria leading to the release of cytochrome $c$ and other PCD inducing mitochondrial factors [30,31]. Indeed, it has already been shown that a short $55^{\circ} \mathrm{C}$ heat treatment of cucumber cotyledons results in cytochrome $c$ being released from the mitochondria into the cytosol [32]. Additionally, mitochondrial release of nuclease activity has been shown to results in the degradation of nuclear DNA following PCD inducing stress [33]. Over-expression of a peroxidase gene would have a significant effect on the generation of ROS following stress treatments. Changing the balance of ROS within the cell would change the point at which cells activated PCD following heat shock. This could explain why we found higher PCD levels in peroxidase transgenics induced by heat stress at temperatures up to $55^{\circ} \mathrm{C}$. Above $55^{\circ} \mathrm{C}$, necrosis predominates in both wild type and transgenics. In this situation, as ROS levels may again be higher in the peroxidase transgenics than in wild type, this could lower the threshold for transition between PCD and necrosis in these cells. Therefore, increased levels of ROS and their dose-dependent effects on PCD versus necrotic cell death decisions can explain the apparently contradictory result of higher PCD levels in peroxidase transgenics induced by temperatures below $55^{\circ} \mathrm{C}$, but lower PCD levels at temperatures above $55^{\circ} \mathrm{C}$. Peroxidase, as with the majority of genes, will not act as a simple on/off switch for PCD. However, regulating the cellular levels of ROS will undoubtedly influence the threshold at which the cell mounts pro-survival versus PCD or necrotic responses. Since $\mathrm{H}_{2} \mathrm{O}_{2}$ is widely regarded as a cytotoxic agent, levels must be critically regulated by the action of antioxidant defence enzymes, which include peroxidases.

In the present study, we have shown the utility of a heat shockbased assay to monitor changes in PCD levels influenced by genes which affect cellular stress perception. The use of this assay to characterise and distinguish between PCD and necrotic modes of death provides an important tool to dissect the influence of introduced genes on cellular survival, in response to diverse stresses that have biological and commercial relevance.

\section{Acknowledgement}

This work was funded by Enterprise Ireland grant SC/97/104 (PD).

\section{References}

[1] P.F. McCabe, A. Levine, P.J. Meijer, N.A. Tapon, R.I. Pennell, A programmed cell death pathway activated in carrot cells cultured at low cell density, Plant J. 12 (1997) 267-280.

[2] P.F. McCabe, C.J. Leaver, Programmed cell death in cell cultures, Plant Mol. Biol. 44 (2000) 359-368.

[3] R. Mensen, A. Hager, P. Salzer, Elicitor-induced changes of wall-bound and secreted peroxidase activities in suspension-cultured spruce cells are attenuated by auxins, Physiol. Plant. 102 (1998) 539-546.

[4] B.K. Kristensen, H. Bloch, S.K. Rasmussen, Barley coleoptile peroxidases. Purification, molecular cloning and induction by pathogens, Plant Physiol. 120 (1999) 501-512.
[5] M. Quiroga, C. Guerrero, M.A. Botella, A. Barcelo, I. Amaya, M.I. Medina, F.J. Alonso, S.M. de Forchetti, H. Tigier, V. Valpuesta, A tomato peroxidase involved in the synthesis of lignin and suberin, Plant Physiol. 122 (2000) 1119-1127.

[6] M. Mader, J. Ungemach, P. Schlob, The role of peroxidase isoenzyme groups of Nicotiana tabacum in hydrogen peroxide formation, Planta 147 (1980) 467-470.

[7] A. Pang, A.M. Catesson, C. Francesch, C. Rolando, R. Goldberg, On substrate specificity of peroxidases involved in the lignification process, $\mathrm{J}$. Plant Physiol. 135 (1989) 325-329.

[8] R. Mittler, E.H. Herr, B.L. Orvar, W. van Camp, H. Willekens, D. Inze, B.E. Ellis, Transgenic tobacco plants with reduced capability to detoxify reactive oxygen intermediates are hyperresponsive to pathogen infection, Proc. Natl. Acad. Sci. U.S.A. 23 (1999) 14165-14170.

[9] E.F. Elstner, A. Heupel, Formation of hydrogen peroxide by isolated cell walls from horseradish, Planta 130 (1976) 175-180.

[10] T. Keller, H.G. Damude, D. Werner, P. Doerner, R.A. Dixon, C. Lamb, A plant homolog of the neutrophil NADPH oxidase gp91phox subunit gene encodes a plasma membrane protein with $\mathrm{Ca}^{2+}$ binding motifs, Plant Cell 10 (1998) 255-266

[11] T. Kawasaki, K. Henmi, E. Ono, S. Hatakeyama, M. Iwano, H. Satoh, K. Shimamoto, The small GTP-binding Rac is a regulator of cell death in plants, Proc. Natl. Acad. Sci. U.S.A. 96 (1999) 10922 10926.

[12] G.P. Bolwell, V.S. Butt, D.R. Davis, A. Zimmerlan, The origin of the oxidative burst in plants, Free Radic. Res. 23 (1995) 517-532.

[13] C.S. Bestwick, I.R. Brown, J.W. Mansfield, Localised changes in peroxidase activity accompany hydrogen peroxide generation during the development of a nonhost hypersensitive reaction in lettuce, Plant Physiol. 118 (1998) 1067-1078.

[14] A. Levine, R. Tenhaken, R. Dixon, C. Lamb, $\mathrm{H}_{2} \mathrm{O}_{2}$ from the oxidative burst orchestrates the plant hypersensitive disease resistance response, Cell 79 (1994) 583-593.

[15] A. Levine, R.I. Pennel, M.E. Alvarez, R. Palmer, C. Lamb, Calciummediated apoptosis in a plant hypersensitive resistance response, Curr. Biol. 6 (1996) 427-437.

[16] R. Desikan, A. Reynolds, J.T. Hancock, S.J. Neill, Harpin and hydrogen peroxide both initiate programmed cell death but have differential effects on defence gene expression in Arabidopsis suspension cultures, Biochem. J. 330 (1998) 115-120.

[17] V. Houot, P. Etienne, A.S. Petitot, S. Barbier, J.P. JP Blein, L. Suty, Hydrogen peroxide induces programmed cell death features in cultured tobacco BY-2 cells, in a dose-dependent manner, J. Exp. Bot. 52 (2001) $1721-1730$

[18] J.F. Dat, R. Pellinen, T. Beeckman, B. Van De Cotte, C. Langebartels, J. Kangasjarvi, D. Inze, F. Van Breusegem, Changes in hydrogen peroxide homeostasis trigger an active cell death process in tobacco, Plant J. 33 (2003) 621-632.

[19] L.M. Lagrimini, R.J. Joly, J.R. Dunlap, T.T.Y. Liu, The consequence of peroxidase overexpression in transgenic plants on root growth and development, Plant Mol. Biol. 33 (1997) 887-895.

[20] M.A.K. Jansen, M. Elfstrand, L. Heggie, F. Sitbon, P.J. Dix, R.N.F. Thorneley, Over-expression of phenol-oxidising peroxidases alters the UV-susceptibility of transgenic Nicotiana tabacum, New Phytol. 163 (2004) 585-594.

[21] B.K. Kristensen, J. Brandt, K. Bojsen, H. Thordal-Christensen, K.B. Kerby, D.B. Collinge, J.D. Mikkelsen, S.K. Rasmussen, Expression of a defence-related intercellular barley peroxidase in transgenic tobacco, Plant Sci. 122 (1997) 173-182.

[22] T. Murashige, F. Skoog, A revised medium for rapid growth and bioassays with tobacco tissue cultures, Physiol. Planta 15 (1962) 473-497.

[23] H. Thordal-Christensen, J. Brandt, B.H. Cho, S.K. Rasmussen, P.L. Gregerson, V. Smedegaard-Petersen, D.B. Collinge, cDNA cloning and characterisation of two barley peroxidase transcripts induced differentially by the powdery mildew fungus Erysiphe graminis, Physiol. Mol. Plant Pathol. 40 (1992) 395-409.

[24] M. Bevan, Binary agrobacterium vectors for plant transformation, Nucleic Acids Res. 12 (1984) 8711-8721. 
[25] R.B. Horsch, J.E. Fry, N.L. Hoffman, D. Eichholtz, S.G. Rogers, R.T. Fraley, A simple and general method for transferring genes into plants, Science 227 (1985) 1229-1231.

[26] R.A. Jefferson, T.A. Kavanagh, M.W. Bevan, GUS fusions: $\beta$-glucuronidase as a sensitive and versatile gene fusion marker in higher plants, EMBO J. 6 (1987) 3901-3907.

[27] A. Stomp, Histochemical localisation of $\beta$-glucuronidase, in: S.R. Gallagher (Ed.), Gus Protocols: Using the GUS Gene as a Reporter of Gene Expression, Academic Press, Inc., USA, 1992, pp. 103-113.

[28] M.M. Bradford, A rapid and sensitive method for the quantification of microgram quantities of protein utilizing the principle of protein-dye binding, Anal. Biochem. 72 (1976) 248-254.

[29] S.V. Lennon, S.J. Martin, T.G. Cotter, Dose-dependent induction of apoptosis in human tumor cell lines by widely diverging stimuli, Cell Prolif. 24 (1991) 203-214.
[30] S.R. McLusky, M.H. Bennett, M.H. Beale, M.J. Lewis, P. Gaskin, J.W. Mansfield, Cell wall alterations and localised accumulation of feruloyl$3^{\prime}$-methoxytyramine in onion epidermis at sites of attempted penetration by Botryis allii are associated with actin polarisation, peroxidase activity and suppression of flavonoid biosynthesis, Plant J. 17 (1999) 523-534.

[31] A. Jones, Does the plant mitochondrion integrate cellular stress and regulate programmed cell death? Trends Plant Sci. 5 (2000) 225-230.

[32] J. Balk, C.J. Leaver, P.F. McCabe, Translocation of cytochrome $c$ from the mitochondria to the cytosol occurs during heat-induced programmed cell death in cucumber plants, FEBS Lett. 463 (1999) 151-154.

[33] J. Balk, S.K. Chew, C.J. Leaver, P.F. McCabe, The intermembrane space of plant mitochondria contains a DNase activity that may be involved in programmed cell death, Plant J. 34 (2003) 573-583. 